\title{
The influence of protein source and basal dietary component on survival in acute experimental fowl typhoid in the chick (Gallus domesticus)
}

\author{
BY R. HILL \\ The Royal Veterinary College, University of London, \\ Department of Animal Husbandry, Boltons Park, Potters Bar, Herts. \\ AND I. M. SMITH \\ The Royal Veterinary College, University of London, \\ Department of Pathology, Royal College Street, London NW1 0TU
}

1. The influence of diet on the survival of chicks inoculated orally at $15 \mathrm{~d}$ of age with Salmonella gallinarum was determined, and in the first experiment the numbers of salmonellae were counted in blood 5 or $7 \mathrm{~d}$ after inoculation to assess their value in predicting survival.

2. Significantly more chicks survived among those given beef powder as the protein supplement in a starch-based diet than among those where fish flour replaced beef powder. The number of salmonellae in blood was significantly higher in chicks given the fish-flour diet than in those given the beef-powder diet, but the relationship between the number of viable organisms in blood and the final survival rate was not close.

3. Whale meat and soya-bean protein gave high survival rates, similar to that given by beef powder, and casein plus gelatin was slightly poorer in this respect.

4. For each high-protein food the level of survival from the acute disease was significantly greater with wheat than with starch as the basal component of the diet.

5. The addition of either condensed beef extract or fish solubles to a standard diet did not influence survival.

The proportion and kind of protein foodstuff used to supplement the diet strongly affected the number of chicks (Gallus domesticus) that survived experimental infection with Salmonella gallinarum (Hill \& Smith, 1969; Smith \& Hill, 1972). Apart from a casein-gelatin mixture the sources of protein in those investigations were the foodstuffs, such as meatand-bone meal or soya-bean meal, commonly used in animal diets. As such meals contain much material besides protein, the effect on experimental fowl typhoid of incorporating foodstuffs of very high (at least $750 \mathrm{~g} / \mathrm{kg}$ ) protein content in the diet was examined. The foodstuffs were used in a diet of semi-purified nutrients (Hill \& Smith, 1969) (starch-based diet) and, as survival after infection was low compared with earlier findings (Smith \& Hill, 1972), these starch-based diets were also compared with wheat-based diets containing the high-protein foodstuffs.

\section{EXPERIMENTAL}

\section{Animals and treatments}

Procedures were essentially those described previously (Hill \& Smith, 1969; Smith \& Hill, 1972). Male chicks of a 'layer-type' hybrid (Thornber 909 line; New House Hatcheries, Mytholmroyd, Yorks.) were obtained, and reared in complete isolation. They were from flocks known to be free from infection with $S$. gallinarum and $S$. pullorum. The experimental diets were given from the day of hatching until the experiments were ended $32 \mathrm{~d}$ later. The chicks were inoculated orally when they were $15 \mathrm{~d}$ old with $1 \mathrm{ml}$ of an alkaline suspension containing $10^{6.4}$ living $S$. gallinarum strain 9 (Smith, 1955). Controls were given the suspension without salmonellae. The birds were weighed when $12 \mathrm{~d}$ old to check the rate of growth with each diet and the controls were weighed again at or near the end 
of each experiment. In Expt 1 approximately $0.3 \mathrm{ml}$ blood was obtained on day 5 or 7 after infection from each of ten infected birds and six control birds/dietary treatment. The number of viable salmonellae was determined by the method of Miles \& Misra (1938). The counts were made by applying $0.1 \mathrm{ml}$ blood and tenfold dilutions in saline $(9 \mathrm{~g}$ sodium chloride/l), to MacConkey No. 3 agar (Oxoid CM 115; Oxoid Ltd, London SE1).

Infected birds that were alive $17 \mathrm{~d}$ after infection were deemed to have survived the acute disease, as deaths after the thirteenth day in this experimental system are rare (Hill \& Smith, 1969; Smith \& Hill, 1972). Bacteriological examinations (Smith \& Hill, 1972) were made of random samples of all birds that died during each experiment, or were killed with the controls at the end of each experiment. These examinations confirmed that $S$. gallinarum was present in all infected birds and absent from all control birds. All deaths in the experiments were therefore regarded as solely due to the infection. The number of survivors/diet were compared by $\chi^{2}$ tests. Survival for one diet being given as greater or poorer than that for another indicated a statistically significant difference between diets $(P<0.05)$.

\section{Diets}

The experimental diets were formulated to provide suitable levels of all nutrients required to maintain health and produce good weight gains in chicks.

Expt 1. Starch-based diets (Hill \& Smith, 1969) contained as supplementary protein $(260 \mathrm{~g} / \mathrm{kg}$ ): casein-gelatin (diet $26 \mathrm{CG}$ ), a beef powder (Bovril Ltd, Enfield, Middx.) (diet 26B), fish flour (The Caledonian Fish Co., Aberdeen) (diet 26F). The effect of these diets on survival after infection was compared on six occasions, using six batches of chicks.

Expt 2. Whale-meat meal (W), liver meal (L) or isolated soya-bean protein (S) provided the supplementary protein in starch-based $(260 \mathrm{~g} / \mathrm{kg})$ and in wheat-based $(160 \mathrm{~g} / \mathrm{kg})$ diets. The activity of these diets was compared (on four occasions with four batches of chicks) with those containing the beef powder, fish flour or casein-gelatin as the protein supplement. Thus, six starch-based diets: diets $26 \mathrm{~B}, 26 \mathrm{~F}, 26 \mathrm{CG}, 26 \mathrm{~W}, 26 \mathrm{~L}$ and $26 \mathrm{~S}$, and six wheatbased diets: diets $16 \mathrm{~B}, 16 \mathrm{~F}, 16 \mathrm{CG}, 16 \mathrm{~W}, 16 \mathrm{~L}$ and $16 \mathrm{~S}$, were tested. The determined and calculated crude protein (nitrogen $\times 6.25$; CP) contents respectively of these foodstuffs and diets, taking $100 \mathrm{~g} \mathrm{CP} / \mathrm{kg}$ as the value for wheat, are shown in Table 1 . The diets were formulated to correspond closely to the simple meat-meal and fish-meal diets (diets $20 \mathrm{M}$ and 20F), whose activity in the experimental disease was known (Smith \& Hill, 1972; Mohammadi, Hill, Smith \& Licence, 1976). Diets 20M and 20F consisted of $(\mathrm{g} / \mathrm{kg}): 200$ meat meal or fish meal, 800 wheat, with a vitamin-mineral supplement (Smith \& Hill, 1972). As the high-protein foodstuffs used in Expts 1 and 2 differed in calcium and phosphorus contents from commercial meat meals and fish meals, bone flour was also included in the wheat-based diets in the same proportion as in the commercial meals. The wheat-based diets therefore consisted of $(\mathrm{g} / \mathrm{kg})$ : high-protein foodstuff 160 , bone flour 40 , wheat 800 , vitamin-mineral supplement 4 . The latter was the same as that used in the starch-based diets (Hill \& Smith, 1969).

Expt 3. The effect on survival after infection of diets containing condensed beef extract (CBE; Bovril Ltd) or fish solubles (FS; British White Fish Meals Ltd, Hull, Yorks.) in a standard diet (diet MPD) (Mohammadi et al. 1976) was determined twice with two batches of chicks. The quantity $(180 \mathrm{~g}$ ) of CBE added to $10 \mathrm{~kg}$ diet MPD was the amount (manufacturer's (Bovril Ltd) estimate) obtained from $2.6 \mathrm{~kg}$ beef powder, which was the weight in $10 \mathrm{~kg}$ diet $26 \mathrm{~B}$. This approach was not possible in deciding the equivalent quantity of FS required. To achieve a reasonable comparison with CBE, therefore, the quantity $(360 \mathrm{~g})$ of FS added to $10 \mathrm{~kg}$ diet MPD was such as to provide the same quantity of solids from FS as from CBE. 
Table 1. The determined crude protein (nitrogen $\times 6.25$ ) contents of high-protein foodstuffs and the calculated crude protein contents of starch- or wheat-based diets*

\begin{tabular}{lccc} 
& \multicolumn{2}{c}{ Crude protein $(\mathrm{g} / \mathrm{kg})$} \\
$\begin{array}{c}\text { Determined, } \\
\text { in } \\
\text { food }\end{array}$ & $\overbrace{\text { Starch-based }}^{\text {Calculated, in diet }}$ & Wheat-based \\
Beef powder & 888 & 216 & 213 \\
Fish flour & 811 & 211 & 210 \\
Casein - gelatin & 879 & 229 & 221 \\
Whale-meat meal & 762 & 198 & 202 \\
Liver meal & 751 & 195 & 200 \\
Soya-bean protein & 907 & 237 & 226
\end{tabular}

- For details, see p. 472.

\section{RESULTS}

\section{Expt 1}

The controls (six chicks/dietary treatment in each replicate) remained healthy throughout and their weights confirmed that diets $26 \mathrm{~B}, 26 \mathrm{~F}$ and $26 \mathrm{CG}$ gave satisfactory weight gains (Table 2; the weights of control birds of the sixth replicate were not obtained). The mean weight gain of chicks given diet $26 \mathrm{~F}$ exceeded, but not significantly, those for diets $26 \mathrm{~B}$ or $26 \mathrm{CG}$.

In each replicate the number of survivors (Table 3) among chicks given diet 26B was greater than that of those given diet $26 \mathrm{~F}$, there being in the whole experiment eighty-one survivors of $252(32 \%)$ chicks given the former diet and nineteen survivors of $252(8 \%)$ chicks given the latter diet. The survival with diet $26 \mathrm{~B}$ was not less than double that for diet $26 \mathrm{~F}$ in any replicate. These respective survival rates were related to the average number of viable salmonellae in the blood 5 or $7 \mathrm{~d}$ after infection, mean viable counts being always greater in the diet 26F-fed than diet 26B-fed birds $(F 9 \cdot 1, P<0.05)$. Nevertheless, the correlation between number of viable salmonellae in the circulation of an individual chick and the period it lived after infection was insufficiently close to predict survival accurately from the viable-count values alone.

\section{Expt 2}

The average weight (at $12 \mathrm{~d}$ of age) of the twelve controls/dietary treatment in the four replicates of this experiment did not vary significantly. In the period from 12 to $25 \mathrm{~d}$ of age (Table 4) weight gains for all diets, with two exceptions, were similar to each other and to those already noted (Table 2) for diets $26 \mathrm{~B}, 26 \mathrm{~F}$ and $26 \mathrm{CG}$ in Expt 1 . The performance of chicks given diet $26 \mathrm{~L}$ was so unsatisfactory that the diet was not used in replicates nos. 3 and 4 . In replicate no. 3 , control chicks given diet $16 \mathrm{~W}$ also made poor weight gains. This was not typical of the diet and no explanation can be given.

Among the starch-based diets the largest difference in the number of survivors after infection was between diet $26 \mathrm{~B}$ and $26 \mathrm{~F}$, the former diet giving greater survival than the latter in each replicate (Table 5). Numbers of survivors with diets $26 \mathrm{~W}$ and $26 \mathrm{~S}$ were similar to those for diets $26 \mathrm{~B}$ and these responses were also greater than that with diet $26 \mathrm{~F}$. The number of survivors with diet $26 \mathrm{CG}$ was intermediate in value and was also poorer than for diet 26B. The patterns for wheat-based diet were similar to those for starch-based diet except that diet $16 \mathrm{CG}$ gave greater survival than diet $16 \mathrm{~F}$, being equivalent to diets $16 \mathrm{~B}, 16 \mathrm{~W}$ and $16 \mathrm{~S}$ in this respect. As noted, control chicks given diet $16 \mathrm{~L}$ grew quite well and it appears reasonable to contrast the activity of this diet in the infection with that of the other 
Table 2. Expt 1 . Mean weights $(\mathrm{g})$ at $12 \mathrm{~d}$ of age and weight gains (g) during the next $20 \mathrm{~d}$, of control chicks (six chicks/diet) given starch-based diets* containing beef powder (diet 26B), fish flour (diet $26 F$ ) or casein-gelatin (diet $26 C G$ ) as supplementary protein

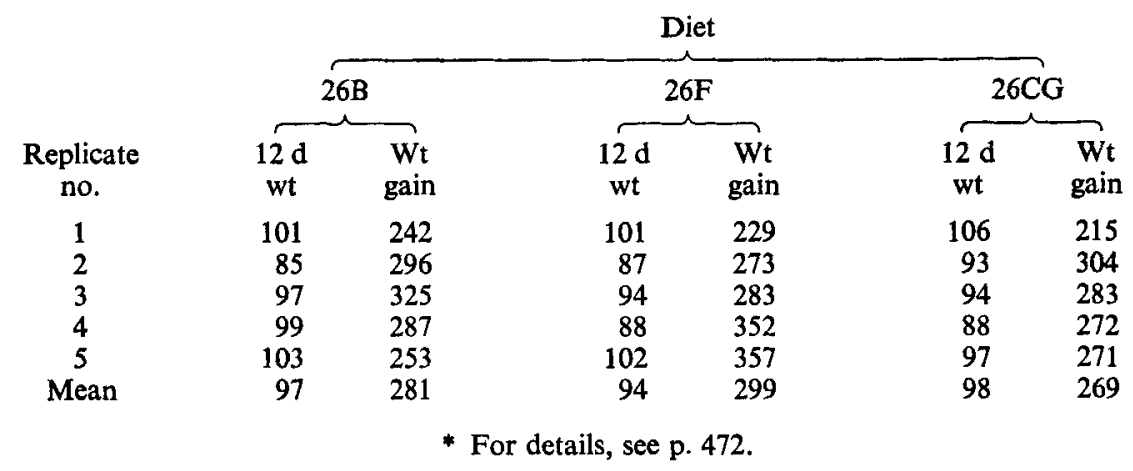

Table 3. Expt 1. The nos. of survivors and the nos. of viable salmonellae in $0.1 \mathrm{ml}$ blood after oral infection with Salmonella gallinarum among chicks given starch-based diets* containing beef powder (diet 26B) or fish flour (diet 26F)

(Values in parentheses indicate the relative survival rate $(\%)$ )

\begin{tabular}{|c|c|c|c|c|}
\hline \multirow{2}{*}{$\begin{array}{l}\text { Replicate } \\
\text { no. }\end{array}$} & \multicolumn{2}{|c|}{$\begin{array}{c}\text { Survival rate } \\
\text { (no. survived }>17 \mathrm{~d} / \text { forty-two } \\
\text { chicks infected) }\end{array}$} & \multicolumn{2}{|c|}{ Log viable count $\dagger$} \\
\hline & Diet 26B & Diet $26 \mathrm{~F}$ & Diet 26B & Diet 26F \\
\hline $\begin{array}{c}1 \\
2 \\
3 \\
4 \\
5 \\
6 \\
\text { Mean }\end{array}$ & $\begin{array}{r}8(19) \\
14(33) \\
14(33) \\
9(21) \\
15(35) \\
21(50) \\
14(32)\end{array}$ & $\begin{array}{ll}2 & (5) \\
3 & (7) \\
1 & (2) \\
4 & (9) \\
4 & (9) \\
5 & (12) \\
3 & (8)\end{array}$ & $\begin{array}{l}2 \cdot 12 \\
2 \cdot 12 \\
2 \cdot 10 \\
1.62 \\
1.61 \\
1.01 \\
1.76\end{array}$ & $\begin{array}{l}2 \cdot 26 \\
2 \cdot 17 \\
2 \cdot 50 \\
2 \cdot 63 \\
2 \cdot 18 \\
2 \cdot 42 \\
2 \cdot 36\end{array}$ \\
\hline
\end{tabular}

* For details, see p. 472 .

$\dagger$ The $\log$ viable counts in replicates nos. 1-4 were determined on day 5, and in replicates nos. 5-6 on day 7 after infection.

wheat-based diets in replicates nos. 1 and 2 (Table 5). Survival with diet 16L was nearly as low $(28 \%)$ as with diet $16 \mathrm{~F}(20 \%)$ and poorer than with diets $16 \mathrm{~B}(50 \%)$ and $16 \mathrm{~S}(47 \%)$.

Survival for each protein supplement in wheat-based diet was at least twofold greater than with the corresponding starch-based diet, apart from diets $26 \mathrm{~B}$ and $16 \mathrm{~B}$ where the ratio was $1 \cdot 8: 1$. The composite effect of the interaction between starch or wheat with supplemental protein therefore produced a wide range of survival (Table 5). Thus only eight of $120(7 \%) 26 \mathrm{~F}$-fed chicks survived after infection compared with forty-seven of 120 (40\%) 16B-fed birds.

Results from the experiment for the effect of diets $16 \mathrm{~B}, 26 \mathrm{~B}, 16 \mathrm{~F}$ and $26 \mathrm{~F}$ on the 'timeto-death' after inoculation illustrates the speed with which the activity of a particular diet was manifested (Fig. 1). The earliest deaths (twenty-one with diet $26 \mathrm{~F}$ but only two with diet $26 \mathrm{~B}$ ) occurred late on the fifth day after exposure to the salmonellae and from that point the influence of diet was readily apparent. After $22 \mathrm{~d}$, the number of deaths had increased to 115 and seventy-five for diets $26 \mathrm{~F}$ and $26 \mathrm{~B}$ respectively but the probable outcome was already obvious on days 6-8. 
Table 4. Expt 2. Weight gain (g) from 12 to 25 d of age of control chicks given starch-or wheat-based diets* containing high-protein foodstuffs

(Mean values for three chicks/dietary treatment)

Replicate

no.

1

2

$\stackrel{4}{\text { Mean }}$

Replicate

no.

1

2

4

Mean
Starch-based diet

$\begin{array}{lccccc}26 \mathrm{~B} & 26 \mathrm{~F} & 26 \mathrm{CG} & 26 \mathrm{~W} & 26 \mathrm{~L} & 26 \mathrm{~S} \\ 150 & 152 & 154 & 167 & 97 & 145 \\ 170 & 173 & 170 & 159 & 72 & 180 \\ 120 & 138 & 104 & 110 & - & 158 \\ 140 & 159 & 156 & 146 & - & 148 \\ 145 & 155 & 148 & 146 & 84 & 158\end{array}$

Wheat-based diet

\begin{tabular}{lccccc}
\hline $16 \mathrm{~B}$ & $16 \mathrm{~F}$ & $16 \mathrm{CG}$ & $16 \mathrm{~W}$ & $16 \mathrm{~L}$ & $16 \mathrm{~S}$ \\
123 & 172 & 164 & 127 & 151 & 153 \\
184 & 167 & 162 & 168 & 162 & 167 \\
138 & 105 & 120 & 57 & - & 144 \\
160 & 167 & 150 & 153 & - & 147 \\
151 & 153 & 149 & 126 & 156 & 153
\end{tabular}

* For details, see p. 472.

Table 5. Expt 2. Nos. of chicks surviving an oral inoculation of Salmonella gallinarum when given starch-or wheat-based diets* containing high-protein foodstuffs

Survival rate

(no. surviving/thirty chicks inoculated)

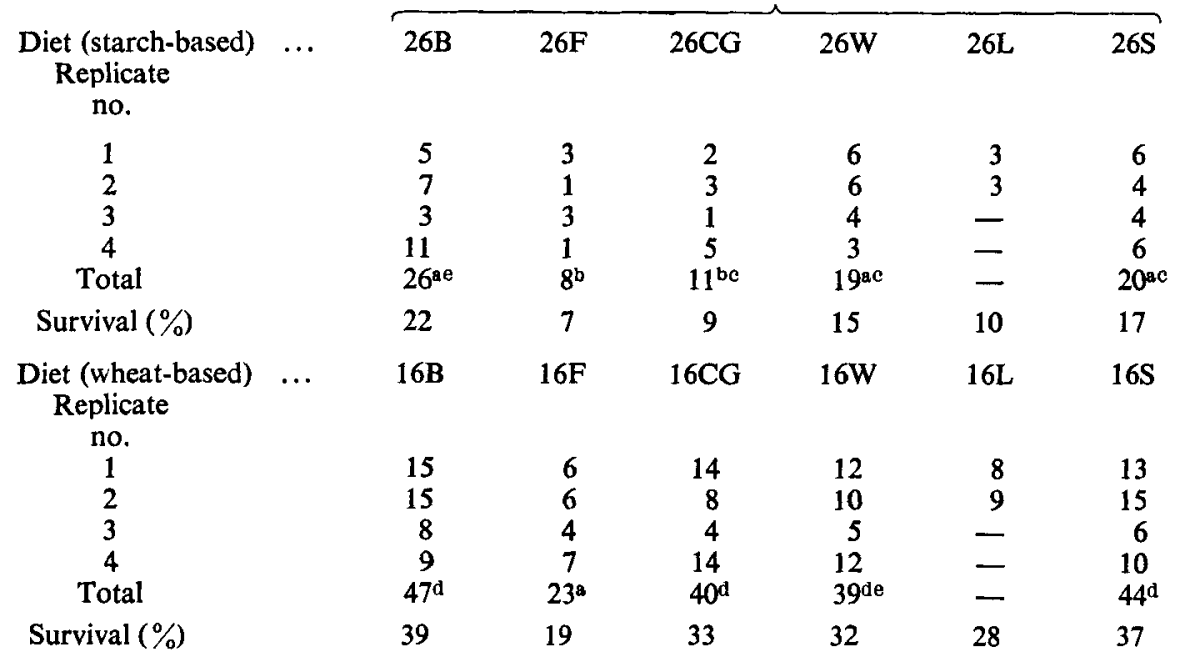

$a, b, c, d, e$, values with different superscripts were significantly different from each other: $P<0.05$ or greater.

* For details, see p. 472.

\section{Expt 3}

The controls given the CBE- or FS-containing diets in both replicates remained healthy and their weight gains were comparable with those noted for controls in Expts 1 and 2 . In each replicate the numbers of survivors after infection was virtually identical for these diets (Table 6). 


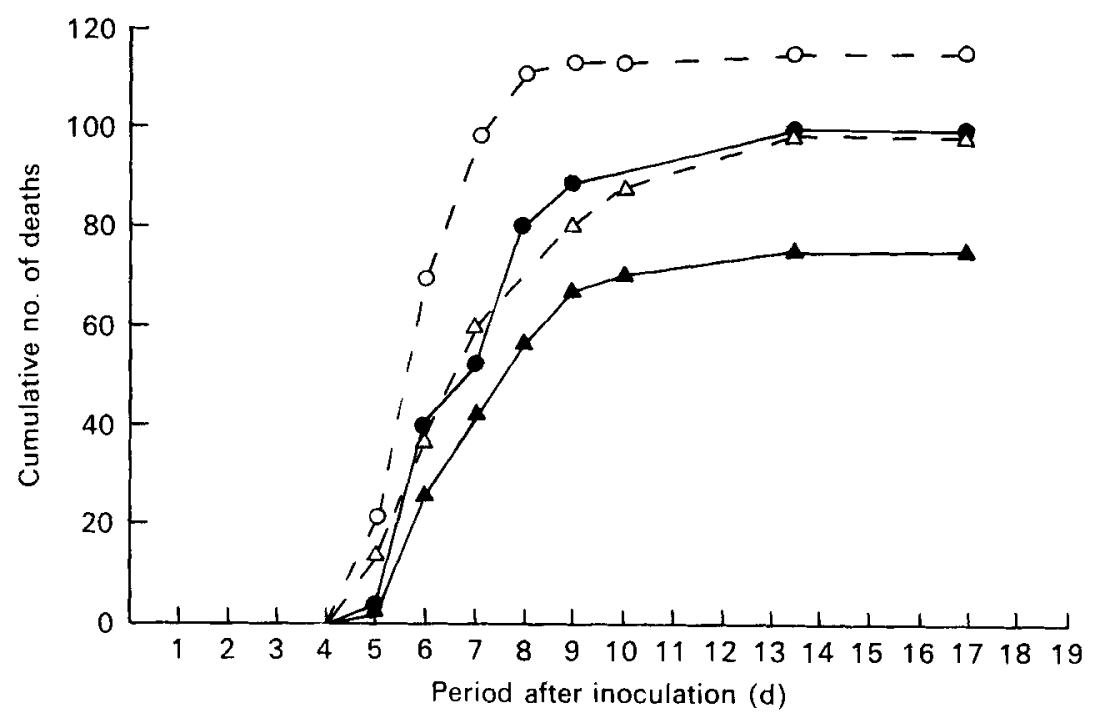

Fig. 1. Expt 2. The cumulative death pattern in birds given wheat- and starch-based diets containing beef powder (diets 16B $(\Delta-\Delta)$ and $26 \mathrm{~B}(\triangle--\triangle)$ respectively) or fish fiour (diets $16 \mathrm{~F}$ (-) and $26 \mathrm{~F}\left(\mathrm{O}_{-}-\mathrm{O}\right)$ respectively) and inoculated orally with Salmonella gallinarum. For details of diets, see p. 472 .

Table 6. Expt 3. Nos. of survivors among chicks infected orally with Salmonella gallinarum when given a standard diet $(M P D)^{*}$ containing condensed beef extract $(C B E)$ or fish solubles $(F S)$

\begin{tabular}{|c|c|c|c|c|}
\hline \multirow{3}{*}{$\begin{array}{c}\text { Replicate } \\
\text { no. }\end{array}$} & \multicolumn{4}{|c|}{ Diet } \\
\hline & \multicolumn{2}{|c|}{$\mathrm{MPD}+\mathrm{CBE}$} & \multicolumn{2}{|c|}{$\mathrm{MPD}+\mathrm{FS}$} \\
\hline & No. surviving $\dagger$ & Survival (\%) & No. surviving $\dagger$ & Survival $(\%)$ \\
\hline $\begin{array}{c}1 \\
2 \\
\text { Total (of seventy }\end{array}$ & $\begin{array}{r}7 \\
8 \\
15\end{array}$ & $\begin{array}{l}20 \\
23\end{array}$ & $\begin{array}{r}8 \\
6 \\
14\end{array}$ & $\begin{array}{l}23 \\
17\end{array}$ \\
\hline infected) & $\begin{array}{l}* \text { For d } \\
+ \text { Of th }\end{array}$ & $\begin{array}{l}\text { tails, see p. } 4 \\
\text { ty-five inocul }\end{array}$ & & \\
\hline
\end{tabular}

\section{DISCUSSION}

These and other results (Hill \& Smith, 1969; Smith \& Hill, 1972; Mohammadi et al. 1976) establish that source of supplementary protein in the diet markedly influences survival from acute experimental fowl typhoid in the chick. This was broadly true whether crude meals or corresponding, but more highly purified forms of protein were used.

The differing level of survival after infection given by fish and meat products was as prominent in Expts 1 and 2 as was previously found (Smith \& Hill, 1972). A complete explanation for this difference remains obscure. Expt 3, in which CBE or FS were used in a standard diet, indicates that the substance(s) affecting survival is not water-soluble. This finding is supported by earlier experiments in which the difference in survival given by water-extracted fish meals and meat meals was almost as large as that with unextracted material (Hill \& Smith, 1972).

Beef and fish (Harvey, 1956) or meat meal and fish meal (Granox Ltd, Wigan, Lancs., 
personal communication; Ellinger \& Boyne, 1965) do not differ strikingly in amino acid composition apart from lysine, methionine, cystine and tyrosine concentrations. The activity in the acute disease of diets with meat products as the supplementary protein, to which lysine, methionine or both had been added to render them equivalent to diets with fish products as supplementary protein, was not decreased (Smith \& Hill, unpublished results). The higher lysine and methionine content of fish products does not therefore explain the dietary effect in the disease. Cystine and tyrosine remain to be tested in this manner.

Fish and meat products also differ strikingly in selenium content. However, survival after infection was not decreased (Smith \& Hill, unpublished results) when enough Se was added to a meat-meal diet to bring its content of this element to a level slightly exceeding that (Scott, Nesheim \& Young, 1969) of a corresponding fish-meal diet.

The injection of iron-dextran greatly enhanced survival in acute, experimental fowl typhoid in chicks (Smith, Hill \& Licence, 1977). Such injections produced proportionally greater survival in those given a fish-meal diet rather than meat-meal diet, but whether $\mathrm{Fe}$ is involved in producing the difference in survival between fish-meal-fed chicks and meatmeal-fed chicks is uncertain. Both fish and meat products are rich in $\mathrm{Fe}$ and the diets used in Expts 1-3 all contained at least $150 \mathrm{mg} / \mathrm{kg}$, i.e. approximately twice the dietary level recommended for chicks. Meat products certainly contain more Fe than fish products but the difference is not large. However, availability and absorption of $\mathrm{Fe}$ depends on more than mere dietary concentration (Underwood, 1971). Absorption of Fe by the chick from diets containing fish or meat products as the only supplementary protein remains to be determined. In human subjects the availability of Fe from fish and meat were alike and greater than that from other foodstuffs (Layrisse, Cook, Martinez, Roche, Kuhn, Walker \& Finch, 1969) but greater from veal than fish muscle (Martinez-Torres \& Layrisse, 1973).

The pronounced influence of the basal ingredient of the diets in Expt 2 on survival in acute experimental fowl typhoid resembled that seen in experimental mouse typhoid (Schneider, 1946, 1956). The principal difference in the basal components in both instances was the substitution of wheat for starch in the diet, a change which increased survival in both diseases. The main nutritional difference in both instances was the provision by wheat of protein and fibre. Partial substitution of starch by an appropriate amount of wheat gluten and fine bran did not alter the level of survival in the chick disease (Smith \& Hill, unpublished results). Schneider $(1967 a, b)$ showed that the factor in wheat responsible for enhancing survival in experimental mouse typhoid arose from growth of Aerobacter sp. on the grain. The substance actually involved (enterobactin) is a cyclic trimer of 2,3hydroxy-N-benzoyl-L-serine (Wawskiewicz, Schneider, Starcher, Pollock \& Neilands, 1971). Although enterobactin is a powerful chelator of Fe, the des-ferri- and Fe-chelate forms are both protective against Salmonella typhimurium infection in the mouse (Schneider, $1967 \mathrm{~b}$ ). The possibility that the greater survival from acute fowl typhoid produced by the wheat-based diets in Expt 2 also arose in this way is being investigated, since chelated $\mathrm{Fe}$ in the diet greatly enhances survival in the infected chick (Smith, Hill \& Licence, 1978).

\section{REFERENCES}

Ellinger, G. M. \& Boyne, E. B. (1965). Br. J. Nutr. 19, 587.

Harvey, D. (1956). Tech. Commun. Bur. Anim. Nutr., Aberd. no. 19.

Hill, R. \& Smith, I. M. (1969). J. comp. Path. 79, 469.

Hill, R. \& Smith, I. M. (1972). Proc. Nutr. Soc. 31, 96A.

Layrisse, M., Cook, J. D., Martinez, C., Roche, M., Kuhn, I. N., Walker, R. B. \& Finch, C. A. (1969). Blood 33, 430.

Martinez-Torres, C. \& Layrisse, M. (1973). Clin. Haemat. 2, 339. 
Miles, A. A. \& Misra, S. S. (1938). J. Hyg., Camb. 38, 732.

Mohammadi, H., Hill, R., Smith, I. M. \& Licence, S. T. (1976). Avian Path. 5, 71.

Schneider, H. A. (1946). J. exp. Med. 84, 305.

Schneider, H. A. (1956). Ann. N.Y. Acad. Sci. 66, 337.

Schneider, H. A. (1967 a). Proc. Nutr. Soc. 26, 73.

Schneider, H. A. $(1967$ b). Science, N.Y. 158, 597.

Scott, M. L., Nesheim, M. C. \& Young, R. J. (1969). Nutrition of the Chicken, p. 323. Ithaca, New York: M. L. Scott \& Associatives.

Smith, H. W. (1955). J. comp. Path. 65, 37.

Smith, I. M. \& Hill, R. (1972). J. comp. Path. 82, 209.

Smith, I. M., Hill, R. \& Licence, S. T. (1977). Res. vet. Sci. $22,151$.

Smith, I. M., Hill, R. \& Licence, S. T. (1978). Res. vet. Sci. (In the press.)

Underwood, E. J. (1971). Trace elements in Human and Animal Nutrition, 3rd ed. New York: Academic Press.

Wawskiewicz, E. J., Schneider, H. A., Starcher, B., Pollock, J. \& Neilands, J. B. (1971). Proc. Natn. Acad. $S c i .$, U.S.A. 68, 2870. 